\title{
Analysis of surface water pollution from abattoirs and the interrelationship between physico-chemical properties (A case study of the New Calabar River)
}

\author{
W. E Tekenah ${ }^{1^{*}}$, P. I Agi ${ }^{2}$, B. B Babatunde ${ }^{3}$ \\ ${ }^{1,2,3}$ University of Port Harcourt, Department of Animal and Environmental Biology, Choba, Port Harcourt, \\ Rivers State.
}

\begin{abstract}
The effects of discharged untreated abattoir waste on water quality and the interrelationship between analysed physico-chemical properties were studied. Samples were taken at the point of effluent discharge, up as well as downstream of source and basic water quality parameters were determined. Correlations were observed between the oxygen availability $\left(B O D_{5} \backslash C O D\right)$ and $C l, M g$ as well as Ca concentrations. An increase in the salt content of the river was observed to correlate with an increase in the Total Solids (TS) and Total Suspended Solids (TSS), while the dissolved oxygen content, also showed an increasing effect with increasing river $p H$ .Using the Prati et al, classification of surface water quality, the river was assessed to be polluted. Although the discharge of human and domestic waste into the water body was a major source of pollution, the introduction of the abattoir effluent midstream had a significant negative effect, contributing to the poor health of the analysed river.
\end{abstract}

Keywords: abattoir, discharge, surface water, pollution, $\mathrm{BOD}_{5}$, New Calabar River

\section{Introduction}

The scarcity of available clean water is on the increase, as a result of various streams of untreated waste constantly being discharged into water bodies. The resulting pollution, which affects the different range of uses of such water bodies as well as its physicochemical properties, could range from activities in the oil and gas exploration (Ite et al, 2013), runoffs from agricultural soils (Maghanga et al 2012), to disposal of sewage into natural waters ( Longe et al, 2010). The meat processing industry in Nigeria has also been implicated as a major contributor in the constant pollution of the water environment, as its different untreated waste streams are often discharged into nearby water courses (Sangodoyin et al, 1992; Benka-coker et al, 1995; Adelegan 2002).

Among the many water quality indicators, the oxygen availability in a particular water system, is indicative of its general health, as a high oxygen demand will ultimately lead to low amounts of dissolved oxygen available to sustain aquatic life (Yakub et al, 2009; Adeogun et al, 2011). According to Ezeoha et al, 2011, abattoir waste have been observed to contain materials having high oxygen demand, notably animal blood. Other studies relating abattoir waste to high oxygen demand (Trift et al, 1992; Sangodoyin et al, 1992; Koech et al, 2012) as well as water borne pathogens (Nafarnda et al, 2012; Atuanya et al, 2012) have also been identified.

The Choba community abattoir, like most in Nigeria, discharges its waste directly into a nearby water course, the New Calabar River. This discharge of untreated abattoir waste, potentially has grave impact on the livelihood of those dependent on the water body. However, the abattoir is not the only identified source of potential pollution, as within the vicinity are operations likely to introduce contamination, such as industrial activity, and the indiscriminate disposal of human, domestic as well as market waste. This study therefore, aims to analyse the pollution status of the New Calabar River, and determine if the abattoir processes amongst others, has a direct impact on the physicochemical properties of the analysed water body. A further aim, would be to identify trends and correlations between the various analysed surface water physicochemical parameters.

\subsection{Study area}

\section{Materials and Methods}

The study area comprises of a community owned abattoir and it's receiving water body, the New Calabar River. Situated about $15 \mathrm{~km}$ from Port Harcourt city, our study area is located in Obio-Akpo Local Government Area of Rivers State, between longitude $6.8985^{\circ} \mathrm{E}$ and latitude $4.8888^{\circ} \mathrm{N}$ of the Greenwich Meridian. The Choba abattoir, situated at the bank of the receiving water course, and in close proximity to the Choba Market, has existed for several decades with an average daily kill of 15-20 cows (personal communication). Among the facilities within the premises is a lairage, where farm animals are housed and a slaughter slab furnished with water taps and a drainage system leading to the investigated the water body. 
Typical operations carried out range from the receiving and holding of livestock to the slaughtering and processing of meat for commercial purposes.

\subsection{Sample Collection}

Grab samples were collected along the effluent flow path from the abattoir. The description of sampling points and the corresponding activities carried out are indicated in Table 1. Water samples were collected into $1 \mathrm{~L}$ clean plastic containers and glass bottles (for oil and grease), at points with reduced human interference on quality status. Sampling was carried out between the hours of 13.15 and $14.30 \mathrm{pm}$, when pollution load was expected to be highest. During sampling, the direction of water flow due to high tide was from downstream upwards (i.e. sampling points 3-2-1). Sampling was done during the wet season of June 2009, few minutes after a light rainfall. To ensure quality assurance, plastic and glassware used, were soaked in $1 \mathrm{M}$ nitric acid overnight (Onianwa, 2001), rinsed with tap water and then with deionized water. Samples were transported to the laboratory in an air tight iced container within 24 hours of collection. All balances and instruments were calibrated prior to use.

Table 1: Description of sapling points.

\begin{tabular}{|c|l|l|}
\hline Sampling Point & \multicolumn{1}{|c|}{ Description } & \multicolumn{1}{|c|}{ Surrounding Activities } \\
\hline $\begin{array}{c}\text { Upstream } \\
\text { (Station 1) }\end{array}$ & $\begin{array}{l}\text { A point (about 100m) before the } \\
\text { introduction of abattoir waste }\end{array}$ & $\begin{array}{l}\text { Residential area, human waste disposal, } \\
\text { fishing }\end{array}$ \\
\hline $\begin{array}{c}\text { Midstream } \\
\text { (Station 2) }\end{array}$ & Point of effluent discharge & $\begin{array}{l}\text { Slaughter house, market, lairage furnace / } \\
\text { processing section }\end{array}$ \\
\hline $\begin{array}{c}\text { Downstream } \\
\text { (Station 3) }\end{array}$ & $\begin{array}{l}\text { A point (about 100m) after the effluent } \\
\text { mixes with the receiving water body }\end{array}$ & $\begin{array}{l}\text { Uncultivated land, domestic waste } \\
\text { dumpsite. Defunct oil servicing company, } \\
\text { market }\end{array}$ \\
\hline
\end{tabular}

\subsection{Experimental design}

Water samples were collected at various points, with varying proximity to the point of discharge. Unstable parameters such as $\mathrm{pH}$ and temperature measurements were recorded in situ, using a $3015 \mathrm{pH}$ meter by Jenwes and a portable mercury in glass centigrade thermometer respectively. The analytical methods used for the determination of the parameters were from the American Public Health Association (APHA) series of standard methods of examination of water and effluent, $20^{\text {th }}$ edition (1998). The amount of salts dissolved in water was measured by silver nitrate titration. Chloride, $\mathrm{BOD}_{5}, \mathrm{COD}$ content in effluent were determined by titrimetric method of analysis, using various reagents. The dissolved solids and total suspended solids in effluent sample were determined using the gravimetric method. The amount of oxygen found in wastewater sample (DO) was determined using the Winkler's titration method, and nitrate concentration in sample determined using the Brucine method, as described by Allen, 1974. Phosphate concentration in effluent sample was determined in accordance with the colorimetric method, APHA 424E with samples analysed at a wave length of $480 \mathrm{~nm}$. The turbidimetric method (based on APHA 3111 D) was used for the determination of sulphate in surface water. Oil and grease (TPH) was determined in effluent using the spectrophotometry method, and heavy metal concentration of surface water samples were determined using the atomic absorption spectrophotometer method. Samples for heavy metal testing were acidified with nitric acid to avoid precipitation, while bottled samples (for oil and grease analysis) were preserved by acidifying with $\mathrm{H}_{2} \mathrm{SO}_{4}$

\section{Results}

The results reveal a significant effect of abattoir processes midstream (discharge of untreated effluent / solid waste, surface runoffs), on the various determined water quality parameters. The oxygen availability as well as metal concentrations varied with proximity to effluent point source, and observed trends in relationships between analysed physico-chemical properties were also evident. The table below (Table 2) presents the result on the physico-chemical analysis of parameters used in determining the impact of abattoir waste on surface water quality. 


\subsection{Effluent effects on surface water oxygen $\left(\mathrm{O}_{2}\right)$ availability}

Surface water oxygen availability from all analysed sites were observed to follow a trend throughout the experiment. The biological and chemical oxygen demand as well as level of dissolved oxygen recorded, were highest upstream and lowest downstream (Fig. 1). The chemical oxygen demand was generally observed to be highest and the dissolved oxygen lowest, showing no significant difference between sampled sites

Table 2: Results of physico-chemical analysis of surface water pollution

\begin{tabular}{|l|l|l|l|}
\hline \multicolumn{1}{|c|}{ Parameter } & \multicolumn{1}{|c|}{ Upstream } & Midstream & Downstream \\
\hline pH & 7.42 & 7.14 & \\
Temperature & 28.0 & 27.0 & 7.00 \\
Salinity & 50.4 & 60.6 & 28.0 \\
Total Solids & 140 & 180 & 101 \\
Total Suspended Solids & 120 & 160 & 320 \\
Chemical Oxygen Demand & 76.0 & 72.0 & 240 \\
Dissolved Oxygen & 4.80 & 4.40 & 52.0 \\
Biological Oxygen Demand & 48.0 & 43.2 & 4.00 \\
Nitrate & 2.60 & 3.50 & 25.6 \\
Phosphate & 0.40 & 0.33 & 1.80 \\
Sulphate & 6.90 & 8.30 & 0.37 \\
Chloride & 28.0 & 33.0 & 6.90 \\
Ammonia & 0.60 & 0.05 & 5.0 \\
Oil and Grease (THC) & 1.00 & 1.00 & 0.06 \\
Iron (Fe) & 0.33 & 0.31 & N.D \\
Manganese (Mn) & 0.029 & 0.026 & 1.00 \\
Zinc (Zn) & 0.08 & 0.35 \\
Magnesium (Mg) & 2.26 & & 0.47 \\
Calcium (Ca) & 0.32 & & \\
& & 0.05 \\
\hline
\end{tabular}

All parameters in $\mathrm{mg} / \mathrm{l}$ except $\mathrm{pH}$ and Temperature $\left({ }^{\circ} \mathrm{C}\right)$ ND - Not detected

\subsection{Effect of Effluent waste on river heavy metal concentration ( $\mathrm{Pb}, \mathrm{Zn}, \mathrm{Mg}, \mathrm{Ca}$, and $\mathrm{Fe})$}

Heavy metal concentration as observed from the various analysed sites varied throughout the experiment. Concentrations observed, were generally lower midstream, except magnesium and calcium concentrations which were recorded to be highest downstream and lowest upstream (Fig 2). Similarly, the salt content, total as well as suspended solids, and chloride concentrations recorded, showed a similar reduction trend downstream. The oil and grease values remained constant at $1.00 \mathrm{mg} / \mathrm{l}$ in all sampling points while ammonia was only detected upstream at $0.60 \mathrm{mg} / \mathrm{l}$. The temperature remained fairly constant throughout the experiment, however the $\mathrm{pH}$ was highest upstream and lowest downstream after the introduction of the abattoir waste. 


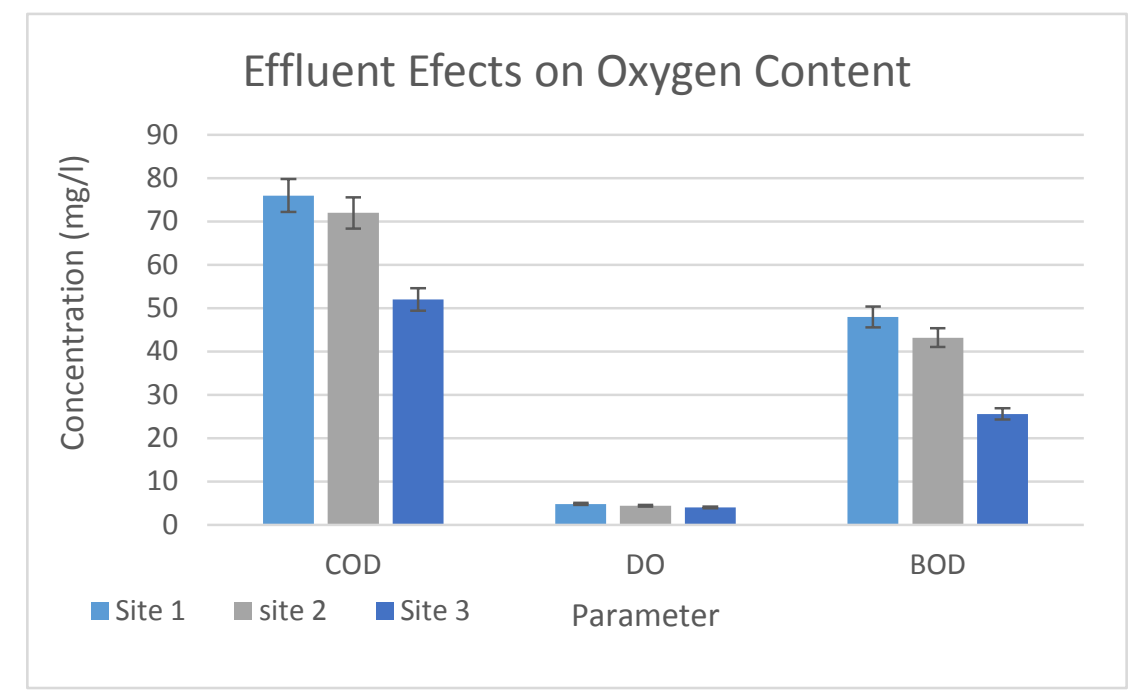

Fig. 2. Effluent effects on oxygen content

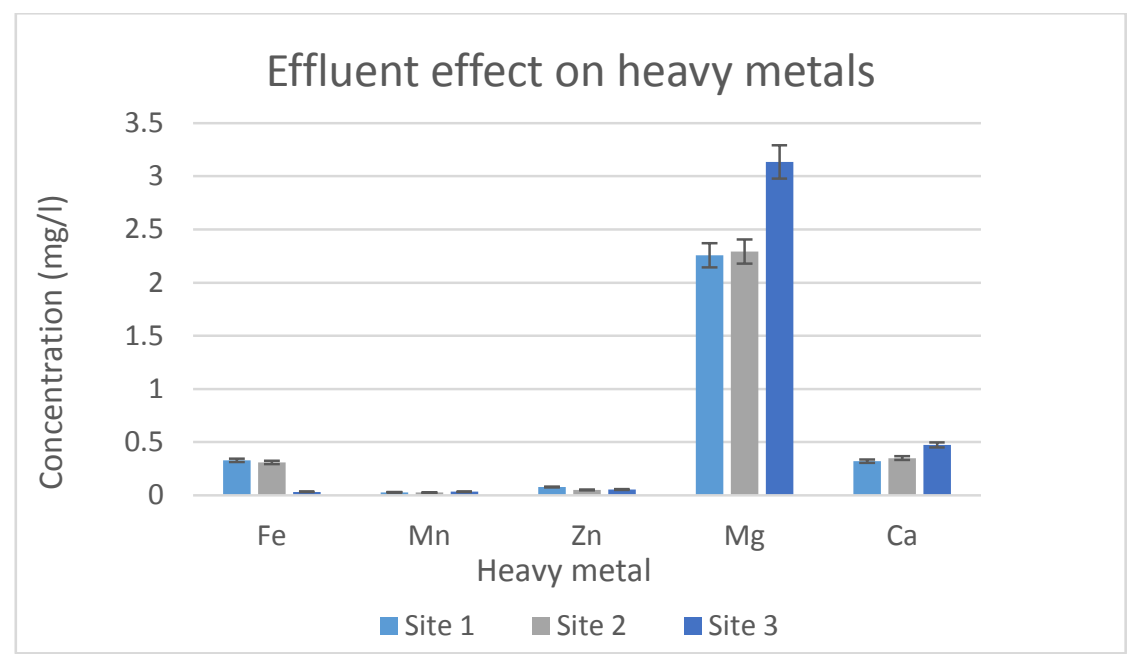

Fig. 3. Effluent effect on heavy metals

\subsection{Correlation of analysed parameters}

Several correlations were observed between analysed physico-chemical parameters (Table 3). Notably, the relationship between the increased total and suspended solids concentration and the rivers salinity, as well as magnesium and calcium concentrations, however, a corresponding reduction effect on the rivers chemical oxygen demand was recorded (Fig 4). Similarly, an increase in total suspended solids was seen to correlate with a corresponding increase in chlorine concentration, and a biological oxygen demand decrease was observed. (Fig 5). A decrease in the chemical oxygen demand of the water body showed a significant relationship with a decrease in the biological oxygen demand as well as an increase in the chlorine, calcium and magnesium concentrations (Fig 6). Similar trends observed were between the dissolved oxygen content and the pH, as well as total suspended solids; iron content and the temperature; chlorine content and the rivers salinity, biological oxygen demand, and heavy metals ( $\mathrm{Mg}$ and $\mathrm{Ca}$ ). 


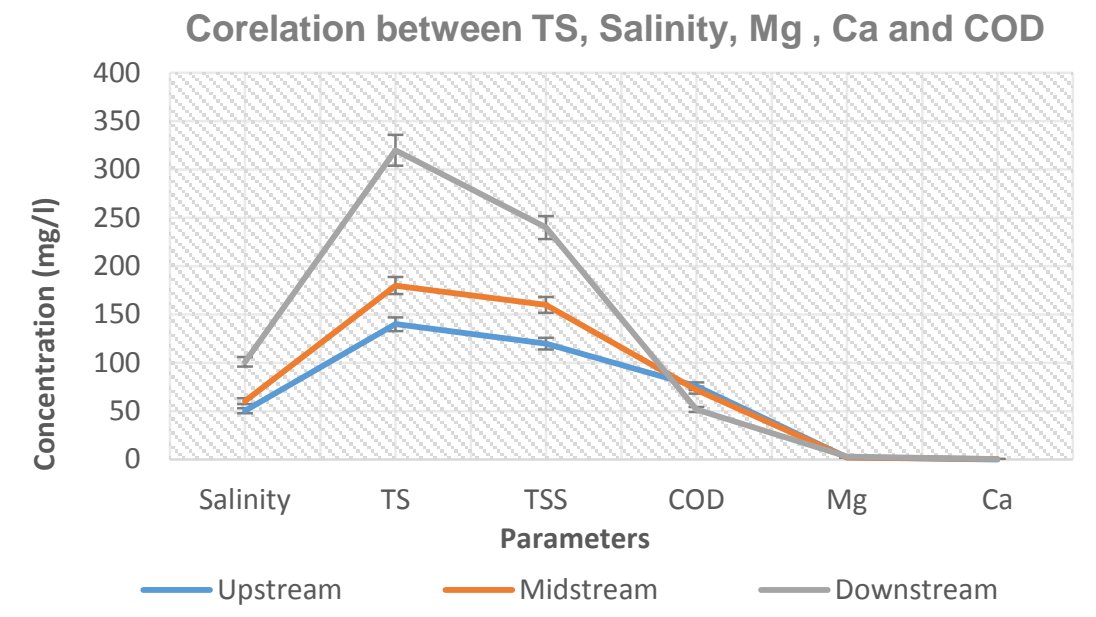

Fig.4: Correlation between Total solids, Salinity, Mg, Ca and COD concentrations

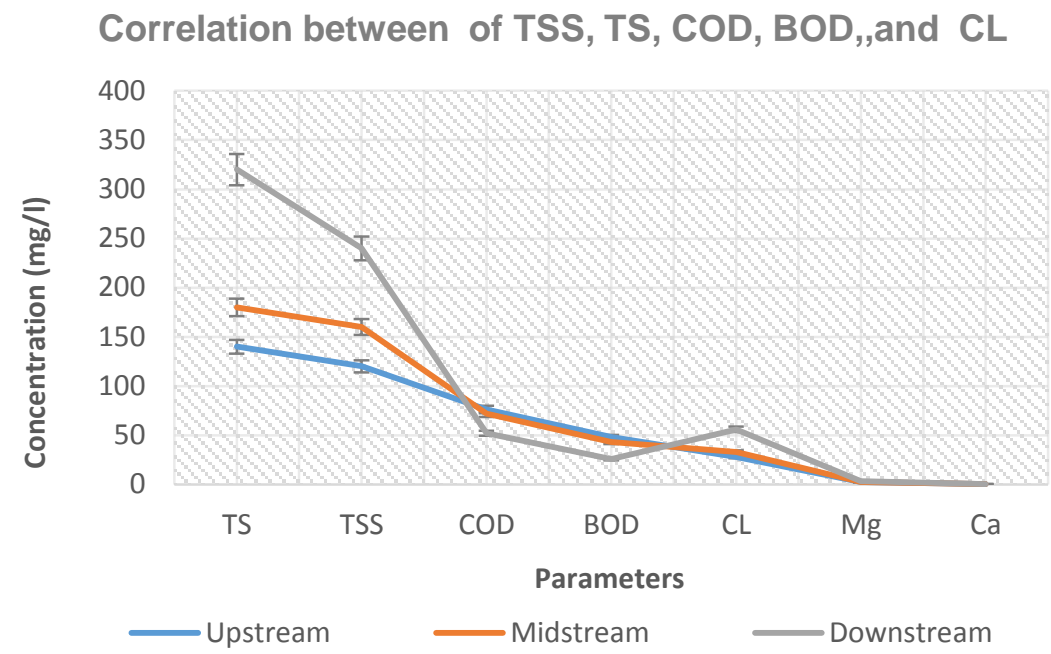

Fig 5: Correlation between Total suspended solids, $\mathrm{COD}, \mathrm{BOD}_{5}$ and Chlorine concentrations

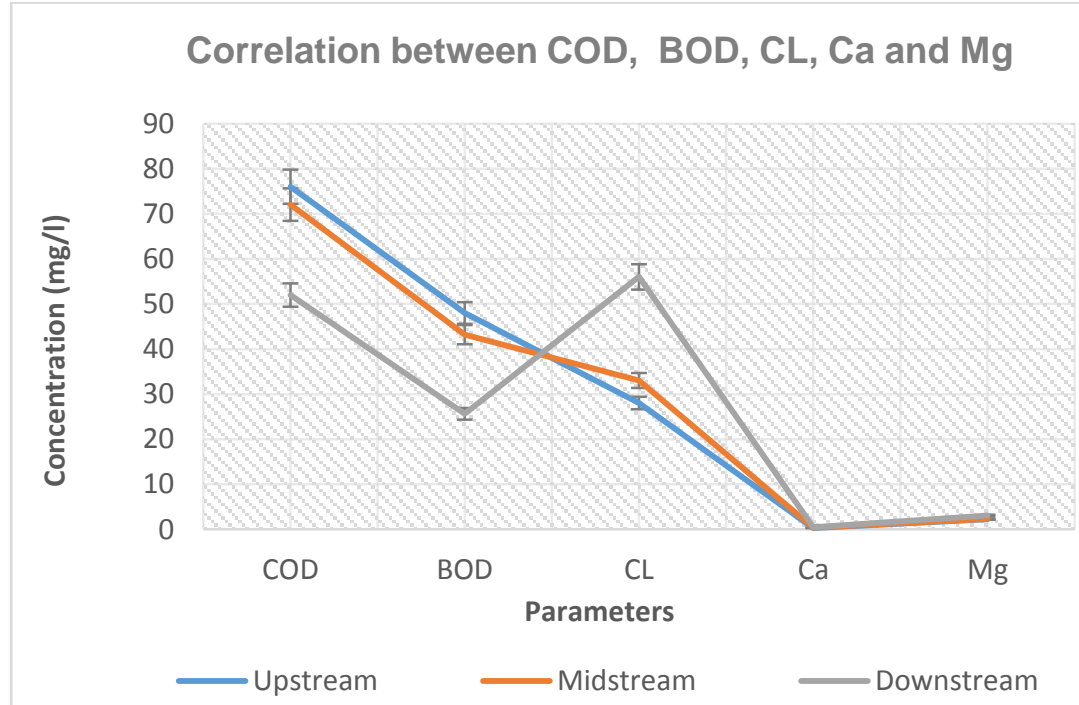

Fig 6: Correlation between $\mathrm{COD}, \mathrm{BOD}_{5}$, Chlorine, Calcium and Magnesium concentrations 


\begin{tabular}{|c|c|c|c|c|c|c|c|c|c|c|c|c|c|c|c|c|c|c|}
\hline Parameter & $\mathrm{pH}$ & \begin{tabular}{|l|} 
Temp \\
\end{tabular} & Salinity & TS & TSS & COD & $B O D$ & NOs & \begin{tabular}{|l|}
$\mathrm{PO}_{4}$ \\
\end{tabular} & $\mathrm{Cl}$ & \begin{tabular}{|l|}
$\mathrm{NHs}$ \\
\end{tabular} & THC & DO & SO4 & $\mathrm{Fe}$ & $\mathrm{Mn}$ & $\mathrm{Zn}$ & $\mathrm{Mg}$ \\
\hline $\mathrm{pH}$ & & & & & & & & & & & & & & & & & & \\
\hline Temp & 0.19 & & & & & & & & & & & & & & & & & \\
\hline Salinity & 0.87 & 0.33 & & & & & & & & & & & & & & & & \\
\hline TS & 0.88 & 0.31 & 0.99 & & & & & & & & & & & & & & & \\
\hline TSS & 0.91 & 0.19 & 0.99 & 0.99 & & & & & & & & & & & & & & \\
\hline COD & 0.85 & 0.36 & 0.99 & 0.99 & 0.98 & & & & & & & & & & & & & \\
\hline BOD & & & & 0.99 & 0.99 & 0.99 & & & & & & & & & & & & \\
\hline $\mathrm{NO}_{\mathrm{s}}$ & 0.33 & 0.87 & 0.76 & 0.74 & 0.65 & 0.78 & 0.75 & & & & & & & & & & & \\
\hline $\mathrm{PO}_{4}$ & 0.62 & 0.89 & 0.14 & 0.17 & 0.28 & 0.11 & 0.16 & 0.54 & & & & & & & & & & \\
\hline $\mathrm{a}$ & & 0.33 & 1 & 0.99 & 0.99 & 0.99 & 0.99 & 0.76 & 0.14 & & & & & & & & & \\
\hline $\mathrm{NH}_{3}$ & 0.95 & 0.5 & -0.65 & 0.67 & 0.76 & 0.63 & 0.67 & 0 & & 0.65 & & & & & & & & \\
\hline THC & - & - & - & . & - & - & - & - & - & - & . & & & & & & & \\
\hline DO & 0.98 & 0 & 0.94 & 0.95 & 0.98 & 0.93 & 0.95 & 0.5 & 0.46 & 0.94 & 0.87 & - & & & & & & \\
\hline $\mathrm{SO}_{4}$ & 0.19 & -1 & 0.33 & 0.31 & 0.19 & 0.36 & 0.31 & 0.87 & \begin{tabular}{|l|l} 
& 0.89
\end{tabular} & 0.32 & 0.5 & - & 0 & & & & & \\
\hline $\mathrm{Fe}$ & 0.01 & 0.98 & 0.52 & 0.50 & 0.39 & 0.54 & 0.50 & 0.95 & 0.77 & 0.51 & 0.31 & - & 0.21 & 0.98 & & & & \\
\hline $\mathrm{Mn}$ & 0.46 & 0.79 & 0.84 & 0.83 & 0.76 & 0.86 & 0.83 & 0.99 & 0.41 & 0.84 & 0.14 & - & 0.62 & 0.79 & 0.90 & & & \\
\hline $\mathrm{Zn}$ & 0.89 & 0.62 & 0.54 & 0.56 & -0.65 & 0.51 & 0.55 & 0.14 & $\mid 0.91$ & 0.54 & 0.99 & - & 0.79 & 0.62 & 0.44 & 0 & & \\
\hline $\mathrm{Mg}$ & -0.78 & 0.47 & 0.99 & 0.98 & 0.96 & 0.99 & 0.99 & 0.85 & 0.01 & 0.99 & 0.53 & - & 0.88 & 0.47 & 0.64 & 0.91 & 0.40 & \\
\hline $\mathrm{Ca}$ & -0.86 & 0.34 & 0.99 & 0.99 & 0.99 & 0.99 & 0.99 & 0.76 & 0.13 & 0.99 & 0.65 & - & 0.94 & 0.34 & 0.53 & 0.85 & 0.53 & 0.99 \\
\hline
\end{tabular}

Table 4: Comparison of obtained results with previous study on the New Calabar River and National standards

\begin{tabular}{|lccc|}
\hline & Present study & Previous study & FEPA \\
Temperature & $27-28$ & $18-19$ & Less than $40^{\circ} \mathrm{C}$ \\
Total Suspended Solids (TSS) & $120-240$ & $440-5120$ & 30 \\
Chemical Oxygen Demand & $52-76$ & $20-92$ & 80 \\
Biological Oxygen Demand & $25-48$ & $6.4-24$ & 30 \\
Ammonia & 0.6 & 1.0 & - \\
\hline
\end{tabular}

All parameters in $\mathrm{mg} / \mathrm{l}$ except Temperature $\left({ }^{\circ} \mathrm{C}\right)$

FEPA - Interim effluent limitation guidelines in Nigeria for all categories of industries (1991)

In comparison to a previous study carried out by Woke et al, 2007 on the influence of abattoir waste on the New Calabar River, results from this study showed higher concentrations (Table 4) in all analysed parameters except in COD concentrations which were observed to be within same range, and ammonia levels, which was only detected upstream. Recorded TSS concentrations were seen to be exceeding recommended limits, however $\mathrm{BOD}_{5}$ concentrations were within permissible limits of the FEPA (1991) standard.

Table 5: Parameters used for the classification of surface water

\begin{tabular}{|lccccc|}
\hline Parameter & Class 1 & Class 2 & Class 3 & Class 4 & Class 5 \\
$\mathrm{pH}$ & $6.5-8.0$ & $6.0-8.4$ & $5.0-9.0$ & $3.9-10.1$ & $\langle 3.9->10.1$ \\
$\mathrm{DO}$ & 7.8 & 6.2 & 4.6 & 1.8 & $\langle 1.8$ \\
$\mathrm{BOD}_{5}$ & 1.5 & 3.0 & 6.0 & 12.1 & $>12.1$ \\
Ammonia & 0.1 & 0.3 & 0.9 & 2.7 & $>2.7$ \\
$\mathrm{COD}$ & 10 & 20 & 40 & 80 & $>80$ \\
TSS & 20 & 40 & 100 & 278 & $>278$ \\
\hline
\end{tabular}


Value of classes; Class $1=$ excellent, Class $2=$ acceptable, Class $3=$ slightly polluted, Class $4=$ polluted, Class $5=$ heavily polluted. (Source Prati et al. 1971.) All parameters in $\mathrm{mg} / \mathrm{l}$ except $\mathrm{pH}$

\section{Discussion}

Oxygen availability in an aquatic ecosystem is an indication of the systems health and general wellbeing. Recorded $\mathrm{BOD}_{5}$ values upstream and at point source $(48$ and $43 \mathrm{mg} / \mathrm{l})$ were observed to be beyond the permissible $30 \mathrm{mg} / \mathrm{l}$ limit of discharge from an industry into a Nigerian inland water (FEPA 1991). From our results, there was an observed significant reduction effect downstream, in not just the $\mathrm{BOD}_{5}$, but the COD and DO concentrations after mixing with effluent midstream. The corresponding elevated upstream concentrations which were contrary to our expectation and differed from a previous study by Woke et al, 2007, can be attributed to tidal movement (Tanganides, 1997) and surrounding activities (mainly discharge of human waste). As opposed to the previous sampling by Woke et al, 2007, sampling in this current study was carried out during a reverse flow tide (downstream flowing upwards), and at a time, when the pollution load was expected to be highest (Immediately after slaughtering). In comparison with recorded $\mathrm{BOD}_{5}$ values obtained, concentrations in the previous study were seen to be within permissible limits, indicating that samples contained a moderate organic load with the potential to lead to a higher degree of pollution if increased. Weather conditions as described by Tanganides, 1997, also determine the quantity of waste, hence; the effects of precipitation, which include surface runoffs, can be implicated as the major cause of observed varying solid concentration difference in both studies, as sampling in this current study, commenced shortly after a brief rainfall.

Recorded $\mathrm{BOD}_{5}$ and $\mathrm{COD}$ concentrations were seen to be reduced as a result of chlorine, magnesium and calcium availability, and this could imply, that the presence of these water pollutants created less favourable conditions for growth of aquatic organisms, hence the reduced demand for oxygen. Most fish, according to Evans and Frick, 2001 are less sensitive than free floating planktonic crustaceans to chloride exposure. These primary producers which fish depend on for food, also help in the control of nutrient accumulation which depletes oxygen and pollution of surface waters results in their destruction which in turn leads to a reduction impact on fish yields (Aina and Adedipe 1991). Further, magnesium toxicity in surface waters has been recorded to be highly dependent on calcium availability, with higher toxicity to aquatic life, occurring in calcium deficient water bodies (Van Dam R.A et al, 2010). An increase in both TS and TSS concentrations, reduced the biological and chemical demand for oxygen as well as increased the salinity of the water. This reduction and increase observed respectively, can be attributed to the presence of discharged abattoir waste, which generally are comprised of materials known to have high demand for oxygen as well as rich in minerals and contain suspended solids (Ezeoha et al, 2011). Among oxygen demanding abattoir waste capable of increasing TS and TSS at point source include condemned meat, undigested ingesta, animal waste, carcases etc. As reported in a study on the effect of physico-chemical properties on estuarine fishes, there was an observed relationship between the acidity of the water body and the amount of free oxygen dissolved to sustain aquatic life. Although contrary to our results, Abowei 2010, observed that the more acidic the $\mathrm{pH}$ the more dissolved oxygen was recorded. Higher dissolved oxygen values however have been studied to be influenced by temperature and abattoir waste (Davies et al 2008), with temperature having a direct effect on water $\mathrm{pH}$

It was observed that although human and domestic waste disposal as well as residue from the defunct oil servicing company contributed to increased concentrations observed both upstream and downstream, the introduction of the abattoir effluent, as well as surface runoff midstream, had a great negative impact on the receiving water body. Sang-Jong et al, 2000, in their study determining pollution from livestock operations, identified intensive agricultural livestock activities as a major point source of pollution to rivers. The density of livestock has also been researched to affect water pollution (Copeland and Zinn, 1998), stating that the higher the density of livestock, the higher the amount of animal waste produced during slaughtering as well as during rearing. Animal blood and paunch manure which in their study is described as a major component of abattoir waste, has been identified to possess high biological and chemical oxygen demand, and could negatively affect the dissolved oxygen content of the receiving water body (Ezeoha et al, 2011) hence the observed correlation between the oxygen demand and dissolved oxygen. The reduced $\mathrm{BOD}_{5}$ and $\mathrm{COD}$ concentrations downstream, shows that the higher concentration observed at point source which is a direct result of abattoir waste discharge, is indeed a great contributor to the waters depleted state. Also, observed increased concentrations midstream in salinity, chloride content, TS and TSS, is further evidence of the detrimental effects of the abattoir waste on the water quality, with higher concentrations downstream attributed to the indiscriminate disposal of human, domestic and market waste into the water body.

The composition of abattoir waste water, has been extensively researched to primarily contain high organic content, adequate alkalinity, sufficient organic biological nutrients (Masse and Masse 2000) and thus significantly low $\mathrm{Zn}$ and $\mathrm{Mn}$ levels recorded were as a result of abattoir operations typically not discharging such heavy metals. Mg levels on the other hand, were observed to have the highest heavy metal concentration, 
and can be attributed to industrial activities, notably metal waste such as scraps from the nearby defunct oil servicing company further downstream.

The data obtained for the TS testing showed that fewer solids dissolved upstream and at the point of discharge and this corresponds with the correlation observed between the total solids concentration and the BOD $_{5}$ as well as COD values. The TSS samples with an average of $173 \mathrm{mg} / \mathrm{l}$ was seen to be much higher than the permissible limit of $30 \mathrm{mg} / 1$ for discharge into surface water bodies. This shows that at all sampled locations, the abattoir waste water as well as various waste streams from surrounding activities being discharged into the river body, contained high quantities of both organic and inorganic particles

According to Ezeoha et al, 2011 in their study, assessing the status of abattoir research in Nigeria, they identified high surface water concentrations of $\mathrm{BOD}_{5}, \mathrm{COD}$, ammonia, as well as suspended solids, as detrimental to aquatic life and river quality. Although the other parameters used in the assessment (Table 5), indicated an acceptable to slight pollution level, the New Calabar River was classified as heavily polluted, using Prati et al's classification of surface water as well as having $\mathrm{BOD}_{5}$ values exceeding recommended FEPA limits.

\section{Conclusion}

In conclusion, our result shows that the analysed water body is contaminated by a variety of sources, with the direct discharge of various streams of untreated abattoir waste, being a major contributor to the poor health of the water body. Abattoir waste, like every other waste, is a resource, and could be utilized in several operations within and outside the activities of the abattoir, such as provision of bio- energy for a self-sustaining cycle (Budiyono et al, 2014), composting in agriculture (Sadik et al, 2010) etc. Findings from this current study indicate that the meat processing industry in Nigeria has a potential to worsen scarcity of clean water availability, thereby adversely affecting the range of uses of such water bodies. It is however recommended that, in line with national and international efforts being made to safe guard the water environment, provide clean water as well as protect human health, the sanitation in our local meat processing industries should be closely monitored. The enforcement of existing health and hygiene regulations as well as the provision of standard equipment and functional units within abattoirs should be encouraged.

\section{Acknowledgement}

The authors are thankful to the staff of the Institute for Pollution Studies (IPS) Rivers State University of Science and Technology, Staff of Rivers State Geographical Information System (RIVGIS), Management of the Choba Community Abattoir, and Mr Japheth for assistance in the laboratory. Special thanks to $\mathrm{Mr}$ Chidiebele Nwankwo.

\section{References}

[1]. Abowei, J. (2010). Salinity, dissolved oxygen, $\mathrm{pH}$ and surface water temperature conditions in Nkoro River, Niger Delta, Nigeria. Adv. J. Food Sci. Technol, 2(1), pp.16--21.

[2]. Adelegan, J. (2002). Environmental policy and slaughterhouse waste in Nigeria, In: 228th WEDC Conference. Calcutta: 228th WEDC Conference.

[3]. Adeogun, A., Chukwuka, A. and Ibor, O. 2011. Impact of Abattoir and Saw-Mill Effluents on Water Quality of Upper Ogun River (Abeokuta). American Journal of Environmental Sciences, 7 (6).

[4]. Aina, E. and Adedipe, N. (1991). Water Quality Monitoring and Environmental status in Nigeria. FEPA Monograph, Lagos, pp.12-59.

[5]. Atuanya, E., Nwogu, N. and Akpor, E. 2012. Effluent Qualities of Government and Private Abattoirs and Their Effects on Ikpoba River, Benin City, Edo State, Nigeria. Advances in Biological Research, 6 (5), pp. 196--201.

[6]. Benka-Coker, M. and Ojior, O. 1995. Effect of slaughterhouse wastes on the water quality of Ikpoba River, Nigeria. Bioresource Technology, 52 (1), pp. 5--12.

[7]. Budiyono, I. and Sumardiono, S. (2014). Kinetic Model of Biogas Yield Production from Vinasse at Various Initial pH: Comparison between Modified Gompertz Model and First Order Kinetic Model.

[8]. Cho, J., Cho, H. and Kim, S. (2000). Heavy contamination of a subsurface aquifer and a stream by livestock wastewater in a stock farming area, Wonju, Korea. Environmental Pollution, 109(1), pp.137--146.

[9]. Copeland, C. and Zinn, J. (1998). Animal waste management and the environment. Washington D.C, USA: Congressional Research Report.

[10]. Davies, O., Ugwumba, A. and Abolude, D. (2008). Physico-chemical Quality of Trans Amadi (Woji) Creek Port Harcourt, Delta, Niger Delta, Nigeria. Journal of Fisheries International, 3(3), pp.92-97.

[11]. Ezeoha, S. and Ugwuishiwu, B. 2011. Status of Abattoir Waste Research in Nigeria. Nigerian Journal of Technology, 30 (2).

[12]. FEPA/FMENV, (1991). Guidelines and Standards for Environmental Pollution Control in Nigeria. Abuja.

[13]. Ite, A. E., Ibok, U. J., Ite, M. U. and Petters, S. W. 2013. Petroleum Exploration and Production: Past and Present Environmental Issues in the Nigeria's Niger Delta. Nature, 1 (4), pp. 78--90.

[14]. Koech, H., Ogendi, G. and Kipkemboi, J. 2012. Status of Treated Slaughter-House Efluent and its Effects on the Physico-Chemical Characteristics of Surface Water in Kavuthi Stream, Dagoretti-Kenya. Research Journal of Environmental and Earth Sciences, 4 (8), pp. 789-796. 
[15]. Longe, E. and Ogundipe, A. 2010. Assessment of Wastewater Discharge Impact from a Sewage Treatment Plant on Lagoon Water, Lagos, Nigeria. Research Journal of Applied Sciences, Engineering and Technology, 2 (3), pp. 274282.

[16]. Maghanga, J., Kituyi, J., Kisinyo, P. and Ng'Etich, W. 2012. Impact of Nitrogen Fertilizer Applications on Surface Water Nitrate Levels within a Kenyan Tea Plantation. Journal of Chemistry, 2013.

[17]. Mass'e D. and Masse, L. (2000). Characterization of wastewater from hog slaughterhouses in Eastern Canada and evaluation of their in-plant wastewater treatment systems. Canadian Agricultural Engineering, 42(3), pp.139--146.

[18]. Nafarnda, W., Ajayi, I., Shawulu, J., Kawe, M., Omeiza, G., Sani, N., Tenuche, O. and Dantong, D. 2012. Bacteriological Quality of Abattoir Effluents Discharged into Water Bodies in Abuja, Nigeria. ISRN veterinary science, 2012.

[19]. National Water Research Institute and University of Saskatchewan, Saskatoon, Canada, SK Canada, (2001). The effects of road salts on aquatic ecosystems. NWRI Contribution. Series No 02:308.

[20]. Onianwa, P. (2001). Roadside topsoil concentrations of lead and other heavy metals in Ibadan, Nigeria. Soil and Sediment Contamination, 10(6), pp.577--591.

[21]. Prati, L., Pavanello, R. and Pesarin, F. (1971). Assessment of surface water quality by a single index of pollution Water Recourses, 5, p.741.

[22]. Sadik, M., El Shaer, H. and Yakot, H. (2010). Recycling of Agriculture and Animal Farm Wastes into Compost Using Compost Activator in Saudi Arabia. J. Int. Environmental Application \& Science, 5(3), pp.397--403.

[23]. Sangodoyin, A. and Agbawhe, O. 1992. Environmental study on surface and groundwater pollutants from abattoir effluents. Bioresource technology, 41 (3), pp. 193--200.

[24]. Standard Methods of Examination of Water and Wastewater, 20th Edition. (n.d.). Washington DC: American Public Health Association (APHA).

[25]. Tangaanides, E. (1997). Pig waste management and recycling; The Singapore experience. Ottawa, Canada: International Development Research Centre, pp.118-137.

[26]. Trift, W. and Schuchardt, F. 1992. Materials flows and possibilities of treating liquid and solid wastes from slaughter houses in Germany. Bioresource Technology, 41 pp. 235-243.

[27]. Van Dam, R., Hogan, A., McCullough, C., Houston, M., Humphrey, C. and Harford, A. (2010). Aquatic toxicity of magnesium sulfate, and the influence of calcium, in very low ionic concentration water. Environmental Toxicology and Chemistry, 29(2), pp.410--421.

[28]. Woke, G. and Wokoma, I. (2007). Influence of abattoir wastes on the physico-chemical parameters of the New Calabar River at Choba, Port Harcourt, Nigeria. African Journal of Applied Zoology I\& Environmental Biology, 9, pp.5--7.

[29]. Yakub, A. and Ugwumba, A. 2009. A study on the macro invertebrate fauna of lower Ogun River at Ishasi, Ogun state, south-west Nigeria. Zoologist (The), 7 (1). 